\title{
Academische Cariothoracale Chirurgie
}

Citation for published version (APA):

Mochtar, B. (2001). Academische Cariothoracale Chirurgie: Ieren, veranderen en leiden. Maastricht University. https://doi.org/10.26481/spe.20010629bm

Document status and date:

Published: 29/06/2001

DOI:

10.26481/spe.20010629bm

Document Version:

Publisher's PDF, also known as Version of record

\section{Please check the document version of this publication:}

- A submitted manuscript is the version of the article upon submission and before peer-review. There can be important differences between the submitted version and the official published version of record.

People interested in the research are advised to contact the author for the final version of the publication, or visit the DOI to the publisher's website.

- The final author version and the galley proof are versions of the publication after peer review.

- The final published version features the final layout of the paper including the volume, issue and page numbers.

Link to publication

\footnotetext{
General rights rights.

- You may freely distribute the URL identifying the publication in the public portal. please follow below link for the End User Agreement:

www.umlib.nl/taverne-license

Take down policy

If you believe that this document breaches copyright please contact us at:

repository@maastrichtuniversity.nl

providing details and we will investigate your claim.
}

Copyright and moral rights for the publications made accessible in the public portal are retained by the authors and/or other copyright owners and it is a condition of accessing publications that users recognise and abide by the legal requirements associated with these

- Users may download and print one copy of any publication from the public portal for the purpose of private study or research.

- You may not further distribute the material or use it for any profit-making activity or commercial gain

If the publication is distributed under the terms of Article $25 \mathrm{fa}$ of the Dutch Copyright Act, indicated by the "Taverne" license above, 
Academische Cardiothoracale Chirurgie

leren,veranderen en leiden

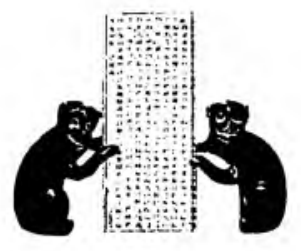





\title{
Academische Cardiothoracale Chirurgie leren, veranderen en leiden
}

Rede uitgesproken bij de aanvaarding van het ambt van Hoogleraar Cardiothoracale Chirurgie aan de Faculteit der Geneeskunde van de Universiteit Maastricht en het Academisch Ziekenhuis Maastricht op vrijdag 29 juni 2001

\author{
Dr. B. Mochtar
}




$$
\text { PPN. 244773548 }
$$


Mijnheer de Rector Magnificus,

Zeer geachte Dames en Heren,

Vandaag zal ik met het uitspreken van deze rede het ambt aanvaarden van hoogleraar Cardiothoracale Chirurgie. De vraag die zich hierbij voordoet is, is hetgeen ik u wil vertellen wel in overeenstemming met het gehele vakgebied dat door mij bestreken wordt d.w.z. zoals de naamgeving doet vermoeden zowel de cardiochirurgie als de thoraxchirurgie? Vanuit welk perspectief zal ik ons vakgebied beschouwen? Ik zou het kunnen hebben over het hartfalen en de indicaties tot bepaalde vormen van chirurgische therapie, zoals de harttransplantatie of over het kwaliteitsbeleid en cardiovasculaire zorg. Een mogelijke vraag die aan de orde zou kunnen komen is, hoe de Cardiothoracale Chirurgie en zijn aandachtsgebieden zich zullen gaan ontwikkelen in de toekomst. Een vraag die relevant en steeds belangrijker is voor een academisch ziekenhuis en ook voor de vorming van onze jonge en toekomstige collegae, die een academische carrière ambiëren en hieraan daadwerkelijk vorm en inhoud moeten geven.

Het is immers pas een jaar geleden dat de naamgeving van ons specialisme bij de Medisch Specialisten Registratie Commissie officieel is veranderd van cardiopulmonale chirurgie in 1975 tot cardio-thoracale chirurgie in 1999. Deze verandering in naamgeving is eveneens kenmerkend voor de vele veranderingen die in ons vakgebied plaatsvinden en hebben plaatsgevonden. Door de snelle ontwikkelingen de afgelopen jaren, die geleidt hebben tot veranderingen of vernieuwingen, wil ik even stilstaan bij de titel van mijn oratie: leren, veranderen en (op)leiden. Zoals in vele managementboeken geschreven staat, gaat aan elk veranderingsproces eerst een leerproces vooraf. Ik neem nu de vrijheid $u$ 
te vertellen hoe ook dit leerproces als een rode draad door mijn medische carrière als cardiopulmonaal chirurg en nu ais cardiothoracaal chirurg gelopen heeft. Met het aanvaarden van mijn benoeming is er een spannende, uitdagende dimensie aan mijn beroep als medisch specialist toegevoegd en wel als onderwijzer en onderzoeker en wordt van mij nu een leidende rol verwacht in de driehoek van patiëntenzorg, onderwijs en onderzoek. Bij deze inleiding moeten u drie woorden opgevallen zijn en wel: leren, verandering of zo $u$ wilt vernieuwing en leiden en opleiden.

Aan de hand van enkele voorbeelden, fundamentele concepten en persoonlijke gedachten zal ik $u$ leiden door het "studielandschap" van de Cardiothoracale Chirurgie in $\mathrm{Ne}$ derland, oftewel de chirurgie bij afwijkingen betreffende het hart, de longen en intrathoracale vaten, met $u$ in perspectief bezien. Hierbij zal ik niet expliciet ingaan op het nijpend personeelstekort in de zorgsector en de beperkte financiële middelen en ruimte, die ook academische ziekenhuizen gewild of ongewild ten deel zijn gevallen. Zoals u reeds weet wordt de Cardiothoracale Chirurgie in Nederland in 13 centra uitgevoerd, waaronder 8 academische ziekenhuizen. Dit aantal en de verdeling zijn door de overheid bepaald en zal de komende jaren door de overheid bepaald blijven worden, waarbij de komende jaren twee nieuwe centra in Enschede (Twentestad) en Den Haag opgericht zullen worden. Met mijn benoeming heeft de capaciteitsgroep Cardiothoracale Chirurgie van het academisch ziekenhuis Maastricht nu een academische status en is de afdeling hierbij officieel geacademiseerd en staan dit jaar de namen en telefoonnummers van onze vakgroep eindelijk in de Universiteitsgids, het Onderzoeksinstituut en het bureau Onderwijszaken vermeld. Waarom is er nog academische Cardiothoracale Chirurgie, terwijl heden ten dage alle routine of regu- 
laire klep- en coronaire bypass operaties eveneens in de zogehelen zes categorale of topklinische ziekenhuizen verricht kunnen worden? Ik kan het ook anders stellen; aan welke eisen dient een academisch specialist Cardiothoracale Chirurgie te voldoen om het predikaat academisch te kunnen waarmaken? Oftewel hoe zou de ideale vorming van een Cardiothoracaal Chirurg met academische ambities eruit moeten zien? Over de ideale vorming tot academisch Cardiothoracaal Chirurg nu en in de toekomst, wil ik uitvoeriger met $u$ ingaan.

\section{Vorming tot academisch Cardiothoracale Chirurgie: lerende chirurgie}

Onderwijs en praktische kennisoverdracht is voor opleiders en stafleden van een vakgroep een dagelijks terugkerende functie voor de assistent in opleiding. Het bijstaan van assistenten in de operatiekamer en ze zien opgroeien tot volleerd chirurg en technicus is een van de meest dankbare rollen die we spelen in de academische Cardiothoracale Chirurgie. Alhoewel we onze bijdrage aan de educatie en training dagelijks leveren, staan we er vaak niet bij stil hoe we de chirurgie onderwijzen. Uiteraard begint de basis van de vorming bij de studentenfase. In het Nieuwe Maastrichts Curriculum voor studenten in de geneeskunde worden plannen uitgezet voor de vorming van de toekomstige arts. Opvallend aan dit nieuwe curriculum is de keuze die de student heeft in het laatste jaar van zijn opleiding tussen een stage van 40 weken in de patiëntenzorg of een wetenschapsparticipatie, met het doel de toekomstig arts te leren in het zelfstandig functioneren en participeren. In de opleidingseisen van de MSRC voor ons specialisme staan uitgebreide richtlijnen, zowel voor de opleider, het opleidingsinstituut, als de 
arts in opleiding. Het trainingsprogramma hangt samen met schoolse activiteiten als onderwijs, begeleiding bij research en evaluatie van onderzoek, het aanleren van intellectuele kennis, het opslaan, onthouden en verspreiden van informatie, observatie en begeleiding, en het proces van progressie door veranderingen in technische vaardigheden aan te tonen. De academie vat bij uitstek de vier deugden voor zo'n leerproces samen, te weten: ontdekking, integratie, toepassing en leren. De belangrijkste verantwoordelijke taak van een academisch instituut is om competente toegewijde dokters, specialisten, die het aangeleerd hebben om open te staan voor een leven lang leren en professionele vernieuwingen en daarbij eveneens een klimaat creëren voor onderzoek en onderwijs. Ik heb specifiek voor de vervolgopleiding tot academisch specialist Cardiothoracale Chirurgie, zoals ik het voor ogen heb, een voorbeeld genomen van de afdeling hartchirurgie van het Johns Hopkins ziekenhuis in Baltimore, Maryland (VS).

De basisbeginselen voor een goed opleidingsprogramma ziet $u$ op de geprojecteerde tabel I.

\section{Tabel I}

Fundamentals of a good residency program

- Place the patient first

- Establish teaching and education as a priority

- Respect the individual

- Create a collegial atmosphere

- Maintain an adequate volume

- Provide evaluation 
De patiënt staat bovenaan en heeft de hoogste prioriteit. Door de patiënt op de eerste plaats te zetten, hebben zowel de assistent in opleiding en de stafchirurg (opleider) de primaire verantwoordelijkheid over de zorg voor de patiënt. Het is eveneens belangrijk om aan het leerproces en de opleiding (vorming) hoge prioriteit te geven. Op dit proces zal ik later nader ingaan. Bovendien is respect voor het individu noodzakelijk voor elke relatie die zich in de tijd in het ziekenhuis ontwikkelt. Tegelijkertijd is de taak van de leider (opleider) ervoor te zorgen dat er in de operatiekamers een eerlijke en collegiale atmosfeer heerst. Zonder deze drie basisbeginselen valt er niet veel te leren en op te leiden. Een adequate volume en variatie van het operatiepalet en voorbereidende diagnostiek zijn een voorwaarde om de assistent een ruime blik te geven over ons vakgebied. Regelmatige evaluatie en terugkoppeling, zowel in negatieve als positieve zin, vervolmaken de basisbeginselen die noodzakelijk zijn voor de ontwikkeling en betrouwbaarheid voor een goed trainingsprogramma. Ik wil met u nog terugkomen op het leerproces en de opleiding. Na het beëindigen van hun opleiding ontwikkelen een aantal chirurgen de egoïstische gewoonte om als solist onafhankelijk te opereren en hun eigen casussen te opereren. Deze chirurgen horen geen verantwoordelijkheid te dragen om ons vak aan assistenten te leren. Als men een bijdrage wil leveren aan een opleidingsprogramma moet men een zogeheten "commitment" aangaan om assistenten op te leiden. Het lijkt mij dat dit een van de voorwaarden is om te participeren in een trainingsprogramma.

In tabel II ziet u voorwaarden geprojecteerd die van toepassing kunnen zijn op elke opleidingskliniek met academische ambities. 


\section{Tabel II}

Johns Hopkins University School of Medicine core values

- Unwavering commitment to excellence

- Integrity

- Respect for the individual

- Dedication to discovery and innovation

- Foster leadership through education and teaching

Al deze basisprincipes kunnen van toepassing zijn in elke praktijk waar assistenten hun training krijgen, in een academische of niet academische kliniek. Het bevorderen van leiderschap door educatie en leren is belangrijk voor de toekomst van ons specialisme. Dit laatste principe is expliciet van toepassing in een opleidingskliniek. Algemene richtlijnen voor opleiders om assistenten in opleiding te leren omgaan met toenemende verantwoordelijke taken zijn o.a. een zorgvuldige selectie van operatiecasussen. Een gelijkmatige progressie van verantwoordelijkheden en de vorming van de opleider zelf tot een excellente eerste assistent en ook van een opleider die zijn eigen beperkingen kent. Een grote voorstander van deze filosofie is Dr. Norman Shumway, die de rol van eerste assistent (opleider) als essentieel beschouwt bij het leerproces van assistenten. Twee belangrijke uitspraken van zijn kant waren "Most of you know by now that the most difficult thing about surgery -even heart surgery-is getting the chance to do it" en "certainly it cannot " matter as much who does the operation, as how it is done". 


\section{De vorming van de juiste sfeer in de operatiekamer}

De ontwikkeling van een collegiale sfeer, waarin gewerkt wordt met goed uitgewerkte protocollen en standaard behandelmethodes, is essentieel voor de opleiding en om een optimaal resultaat voor de patiënt te halen. De samenwerking van meerdere individuen in een operatiekamer waar cardiothoracale en cardiovasculaire chirurgie verricht wordt, is essentieel en noodzakelijk om uitstekende resultaten te krijgen. Samenwerking leidt tot verbetering door effectieve interactie en discussie. Een voorbeeld hiervan is de aortachirurgie. Met de introductie van de thoraco-abdominale aorta aneurysma chirurgie door de nieuwe hoogleraar vaatchirurgie in het azM is in dit jaar geïntegreerd en in multidisciplinair verband met de afdeling Cardiothoracale Chirurgie, een kwaliteitsimpuls gegeven aan de aortachirurgie, waarbij tevens technieken ter preventie van cerebrale- en ruggemergschade geintroduceerd zijn. Samen proberen

we voor bovengenoemde aortachirurgie een centrumfunctie te vervullen. Een ander voorbeeld van samenwerking: de longchirurgie voor longkanker kan niet meer in bilateraal verband met longartsen beoefend worden. Meerdere disciplines waaronder radiotherapeuten, oncologen uit een chirurgische discipline of interne geneeskunde en patholooganatomen dienen in de besluitvorming betrokken te worden. Ik hoop dat samenwerking met onze collegae longchirurgen van het specialisme algemene heelkunde in den lande de komende jaren geëffectueerd zal worden. Maar geen kinderhartchirurgie in Maastricht. Deze chirurgie hoort thuis in een centrum waar voldoende patiënten per jaar geopereerd worden door een team, die de continue specifieke expertise in huis heeft, om resultaten te bereiken, die zich kunnen meten met grote internationale klinieken. 


\section{Terug naar de operatiekamer}

Als cardiochirurgen worden we regelmatig vergeleken met een andere analoge groep individuen en wel de luchtvaartpiloten. Een schatting is dat $70-80 \%$ van de ongelukken bij burgerluchtvaartmaatschappijen te wijten is aan menselijke factoren. Het merendeel van dit menselijk falen kan gerelateerd worden aan communicatiestoornissen. Sociologische barrières schijnen het doorgeven van cruciale informatie van onderen naar boven te onderdrukken, b.v. van de navigator naar de co-piloot, of van de co-piloot naar de piloot. Een gelijkwaardig scenario kan in onze operatiekamer plaatsvinden b.v. van de assistent naar de chirurg, van de perfusionist naar de assistent of chirurg, of van de operatiekamerassistente naar de chirurg, van de chirurg naar de anesthesist enz. Dit scenario verwijst direct naar de opleidingsaspecten van de cardiochirurgie, waarbij het even belangrijk is voor assistenten te leren om complicaties te voorkomen, als het leren aanleggen van een knoop en hechtingen bij klepoperaties en het herkennen van cardiale en pulmonale problemen. Voor de overdracht van effectief onderwijs en training in de operatiekamer wordt een open en veilige omgeving gevraagd, waarbij directe en open communicatie tussen alle disciplines vanzelfsprekend is en aangemoedigd wordt. In het bijzonder is het belangrijk om suggesties te accepteren en de zogeheten "autoriteitsgradiënt" in de operatiekamer te elimineren. De hoofdchirurg of eerste chirurg moet wel de leider van dit samenwerkingsver-

- band zijn. 


\section{Ontwikkeling van een trainingsprogramma}

In een trainingsprogramma zal als belangrijk onderdeel een getrapt schema van verantwoordelijkheden aanwezig moeten zijn. De assisterende chirurg die de operatie superviseert, kan de operatie effectief controleren van de linkerkant van de operatietafel. Vertrouwen in elkaars techniek van myocardprotectie en het herkennen van de gedeelde verantwoordelijkheid van operatietechnieken, zijn noodzakelijke eigenschappen om een goede opleider in de operatiekamer te worden. Het is belangrijk om de operatie de eerste keer correct uit te voeren, waarbij geen compromis wordt gedaan aan de graad van perfectie. We moeten assistenten laten leren van casus tot casus met periodieke evaluaties. Alhoewel gedeelde verantwoordelijkheid subjectief is, kan men de technische vaardigheden van de assistent eveneens goed beoordelen wanneer hij/zij als eerste assistent functioneert. De juiste operatiegevallen kunnen dan geselecteerd worden. Verschillende delen van de operatie kunnen dan in zijn geheel of gedeeltelijk uitgevoerd worden, afhankelijk van de operatieve ervaring. Dit kan inhouden het verrichten van de sternotomie, cannulatie, arteriotomie, het hechten en sluiten. Een effectieve opleider geeft de plaats aan waar gecannuleerd dient te worden of waar de hechtingen geplaatst dienen te worden en legt elke stap van de procedure uit, in volgorde van belangrijkheid. Alle potentiële gevaren en bijbehorende specifieke maatregelen moeten uitgelegd worden ter completering van het geheel. Vele van deze scenario's moeten gegroepeerd worden rondom potentiële onverwachte moeilijkheden bij operatieve handelingen. De evaluatie van het functioneren van de assistent in opleiding is een belangrijk onderdeel van het opleidingsprogramma. Specifieke kritiek zal onder vier ogen moeten ge- 
beuren en niet in het openbaar. Naast de kritische beschouwingen over de technische vaardigheden van de assistent, moet er ook een positieve terugkoppeling plaatsvinden. Evaluatie van het opleidingsprogramma is een absolute noodzaak om een hoog opleidingsniveau en ontwikkeling te bewerkstelligen. Deze evaluaties zijn soms moeilijk te verwerken, maar zijn belangrijk om de juiste terugkoppeling te verkrijgen, waardoor de individuele prestatie en ook het opleidingsprogramma als geheel verbetert. Essentieel voor een assistent in opleiding zijn goede rolmodelten, inspiratie tot hard werken, goede relaties en brede loyaliteit. De overdracht van het vak chirurgie in de breedste zin van het woord is zowel kunst als kunde (wetenschap). Het kan niet genoeg gezegd worden, hoe belangrijk het is om een opleidingsprogramma als hoge prioriteit naar voren te brengen. Assistenten zijn er niet alleen om ondersteuning te verlenen. Het onderwijs van assistenten moet in balans zijn met de andere taken, waaronder patiëntenzorg en onderzoek. Assistenten Cardiothoracale Chirurgie moeten ook de vaardigheid bijgebracht worden, naast de technische en klinische expertise, om managementeigenschappen aan te leren, hetgeen noodzakelijk is om groepen in de gezondheidszorg te leiden. Zonder twijfel geeft het persoonlijke voldoening, wanneer assistenten hun vaardigheden en vorderingen, zowel binnen en buiten de operatiekamer, ontwikkelen. Het ultieme doel van een opleidingsprogramma is de ontwikkeling van toekomstige leiders in ons specialisme. De capaciteitsgroep Cardiothoracale Chirurgie in Maastricht wil haar bijdrage leveren aan de opleiding van toekomstige specialisten. Maar wat voor perspectieven zijn er voor onze toekomstige collegae? Cardiothoracale Chirurgie blijf in mijn ogen een uitdagend beroep, dat persoonlijke satisfactie geeft. Een Cardiothoracaal Chirurg in een academie be- 
zit hel unieke potentieel om veeleisende klinische uitdagingen met een verantwoordelijke rol als opleider te integreren met nieuwe uitdagende ontwikkelingen in ons vakgebied. De start in deze academische discipline in het nieuwe millennium is echter niet zo simpel als in de jaren zestig van de vorige eeuw. Heden ten dage zijn de standaard klinische operaties goed beschreven en veel van de klinische fysiologie is omschreven. De basale wetenschappelijke research richt zich voornamelijk op genetische, moleculaire of cellulaire fenomenen, waarbij minder fondsen worden vrijgemaakt voor observatie en research bij grote proefdieren. In het onderzoeksinstituut CARIM (cardiovascular research institute Maastricht) verricht de capaciteitsgroep experimenteel onderzoek bij grote proefdieren, waarbij modellen voor klepimplantaties ontwikkeld worden om klepfuncties te meten. Dit gebeurt in samenwerking met de afdeling experimentele heelkunde van de afdeling Cardiothoracale Chirurgie van de Katholieke Universiteit Leuven. Basale wetenschappelijke research is altijd de hoeksteen geweest voor een solide academische carrière, ook voor cardiochirurgen. In het verleden hebben vele Cardiothoracale Chirurgen in het laboratorium met grote proefdieren chirurgische technieken ontwikkeld, de techniek van de hartlongmachine verfijnd of klinische concepten gevalideerd. Ook hier wil de capaciteitsgroep Cardiothoracale Chirurgie van het academisch ziekenhuis Maastricht haar bijdrage in leveren, met name in het experimentele laboratorium met grote proefdieren, zoals schapen en geiten. 


\section{De aanvang van academische Cardiothoracale Chirurgie}

De klinische praktijk en bedrijfsvoering zijn ook in de academie competitief geworden met geringe compensatie in financiële zin voor jonge collegae en waarbij grote betekenis wordt gehecht aan resultaten en kosten op korte termijn. Daarom wordt de academische missie moeilijk, want het opleiden van assistenten creëert ook een verantwoordelijkheid voor een plaats op de arbeidsmarkt. Met een relatief overschot aan cardiothoracaal chirurgen en de toename van het aantal centra in categorale of topklinische ziekenhuizen, wordt de rol van de academische medische centra zodanig, dat meer ingespeeld zal moeten worden op complexe chirurgie met een hoog risico, congenitale hartchirurgie, assist-devices en transplantaties. Juist met deze uitdagingen kan men een succesvolle carrière als academisch Cardiothoracaal Chirurg verwezenlijken. Om een succesvolle academische carrière te creëren moet men per definitie en niet als optie een bijdrage leveren aan onderwijs en wetenschappelijk onderzoek. Indien men geen idee heeft hoe men voor zichzelf een bagage(portefeuille) van academische waarden kan creëren is het beter om niet in een universitaire setting te werken. Hieronder versta ik het uitstippelen van o.a. promotieonderzoek of een specialisatie in een specifiek onderdeel van het vakgebied, waarbij u samenwerking moet zoeken met andere faculteitsleden. De klinisch georiënteerde cardiothoracaal chirurgen zouden zich meer kunnen richten op de minder kostbare en op een enkel centrum gerichte retrospectieve studies dan de duurdere prospectieve studies met meerdere centra. Echter het ontwerpen van deze studies vereist een wetenschappelijke discipline en een toegewijd plan van aanpak om hypotheses 
en methoden te ontwikkelen en waarbij pogingen in het werk gesteld moeten worden om samen te werken met specialisten op het gebied van klinische research, gezondheidswetenschappers en statistici. Dat wil niet zeggen dat men perse in een academische setting moet werken om een bijdrage te kunnen leveren aan onderwijs en wetenschap. In het bijzonder kunnen bepaalde vormen van klinisch onderzoek evenzogoed in een algemeen, topklinisch ziekenhuis gedaan worden indien er een groot volume aan ingrepen, een breed palet aan operaties, ervaring in klinische research en tevens prioriteit en steun gegeven wordt. Er bestaat ook een algeheel misverstand dat de academie op klinisch gebied minder competitief is dan een categoraal perifeer ziekenhuis; de technisch begaafde chirurgen zouden naar de perifere algehele praktijk gaan en de technisch minder begaafde chirurgen naar de academie. Nogmaals dit is waarschijnlijk een mythe. De klinische praktijk in een academisch medisch centrum wordt gedeeltelijk bepaald door quaternaire zorg (b.v. transplantaties, hoog risico revascularisatie en klepoperaties, nieuwe technologieën) en wordt beoordeeld op dezelfde criterias zoals die voor niet-academische categorale topklinische ziekenhuizen gelden, alhoewel ze tegelijkertijd de verantwoordelijkheid voor een opleiding tot Cardiothoracaal Chirurg en onderwijs en onderzoek dragen. Dezelfde variabele resultaten op korte termijn worden in beide klinische kaders nadrukkelijk gemeten (zoals kosten, duur van ziekenhuisopname, getallen van mortaliteit en morbiditeit). Het zal moeilijk worden voor de individuele stafleden Cardiothoracale Chirurgie in een academisch ziekenhuis om productief te zijn zowel op het gebied van de kliniek, onderwijs, academische taken en bestuur/management taken. Om een levendige, productieve klinische afdeling als geheel te behouden, moeten de bestuurders en hoofden 
van afdelingen erkennen dat de klassieke verwachtingen van productiviteit in alle vier bovengenoemde gebieden niet altijd te realiseren zijn. Indien basaal wetenschappelijk onderzoek of klinisch onderzoek een frustrerende bezigheid wordt, zal het een minder belangrijke plaats krijgen, waarbij uiteindelijk het staflid kiest voor een specifieke klinische taak of vertrekt naar een categoraal ziekenhuis. De toekomstige academische beleidslijnen binnen een afdeling of capaciteitsgroep heeft het risico in zich, dat de vakgroep dan verdeeld wordt in individuen die alleen klinisch bezig zijn en of stafleden die alteen met onderzoek of formeel onderwijs bezig zijn. In de huidige competitieve markt is het een vereiste dat er juist een gebalanceerd evenwicht bestaat in deze triade. Het is een ongewenste situatie indien alleen de onderzoekers het beleid in een academische kliniek gaan bepalen, zonder de kliniek ofwel de patiëntenzorg te steunen. Het unieke faculteitslid van een vakgroep, die zowel wetenschappelijk, onderwijskundig en betrouwbaar klinisch productief is, is moeilijk te vinden en zal gevormd moeten worden. Echter de sleutel tot succes bij een academische carrière wordt uiteindelijk individueel bepaald. Er zijn vier wederkerende thema's die voor het betreffende individu benoemd moeten worden om een succesvolle carrière in de academische Cardiothoracale Chirurgie te volbrengen, t.w. eerlijkheid, discipline, gelegenheid en steun die men krijgt. De eerlijkheid betreft zowel de intellectuele als emotionele kant. Bij integriteit en eerlijkheid tegenover zichzelf zullen de

- juiste beslissingen omkleed met de juiste redenen en op het goede moment gemaakt kunnen worden. Het concept van discipline geeft de mogelijkheid om met meerdere zaken tegelijk bezig te zijn, hetgeen een vereiste is voor ons beroep. Het hoofd van de afdeling of het instituut moet $u$ een reële gelegenheid geven om te groeien en ontwikkelen, zonder 
valse beloften, zonder verborgen agenda's, zonder afgebroken initiatieven. $U$ kunt deze carrière niet in een vacuüm ontwikkelen. Steun kan en moet gevonden worden in de vorm van een mentor/supervisor, middelen, personeel, salaris of tijd om research te doen. Voor velen van ons is er een genoegdoening om een academische carrière in de Cardiothoracale Chirurgie te ambiëren. We dragen de verantwoordelijkheid om de erfenis van geweldige pioniers van het eerste uur, die baanbrekend werk voor ons gedaan hebben, over te nemen. De pioniers zitten onder ons. De klinische uitdagingen zijn elke dag uniek en drijven de limiet van ons technisch kunnen en emotionele krachten omhoog. Terwijl ons specialisme verandert, is het onze verantwoordelijkheid hieraan deel te nemen en een bijdrage te leveren aan veranderingen, anders dan het alleen maar over te erven. Het opleiden van de volgende generatie Cardiothoracaal Chirurgen is niet alleen een enorme verantwoording, maar men krijgt er ook veel voor terug. Een academisch cardiothoracaal chirurg krijgt zijn beloning in verschillende vormen terug: men neemt dagelijks deel aan hedendaagse professie: men ziet de assistenten in de praktijk groeien tot succesvolle collegae van ons specialisme: en uiteindelijk helpt men vorm te geven aan de toekomst van ons specialisme.

\section{Voorwaarden voor verandering of vernieuwing in de academische Cardiothoracale Chirurgie}

Zoals het eenvoudigweg onmogelijk is om een goed chirurg te worden door middel van boekenwijsheid, geldt dit eveneens voor administratieve of managementtaken in de huidige tijd. Met een degelijke basiskennis na de opleiding is de logische volgende stap in de vervolgopleiding van de Cardiothoracaal Chirurgen het assisteren en observeren van 
senior of topchirurgen in de operatiekamer. In dit proces leert men de chirurgische vaardigheden die men wil overnemen en enkele die best vergeten mogen worden. Hetzelfde geldt voor administratieve- en managementvaardigheden. Indien u zorgvuldig individuen op uw afdeling, divisie of vakgroep en instituut observeert, zult u personen aantreffen die uitstekend werk verrichten als managers op allerlei niveaus. Ook op dit gebied moet men niet proberen het wiel uit te vinden. Hetzelfde geldt voor bestuurlijke werkzaamheden. Dit betekent dat $u$ ook actief moet zoeken naar mogelijkheden om organisatorische talenten te ontplooien en u niet opsluit in de operatiekamer of het laboratorium. Immers deze ervaringen kunnen toekomstige carrièreperspectieven vergroten. Het is soms moeilijk om de bestuurlijke van de leiderschapskwaliteiten te onderscheiden. Mijn ervaring is dat leiders (leidende chirurgen) inspireren en dat administrateurs zelden zo overkomen. Hierbij wil ik de citaten aanhalen van Hatcher in 1988 uit het artikel: "There is life outside the operating room". Voor de tweede wereldoorlog en recent in $\mathrm{Ne}$ derland werden ziekenhuizen gerund door dokters. Terwijl de dokters de militaire dienst in moesten, was het noodzakelijk dat lekenadministrateurs de zaken moesten regelen, zodat aan het eind van de oorlog, een nieuwe professie - ziekenhuis of gezondheidsadministratie - gevestigd was. De overdracht van de autoriteit van de arts naar de administrateur toe ging lange tijd door, veroorzaakt door eigen falen, want de dokters wilden gevrijwaard blijven van administratieve en zakelijke beslommeringen van het ziekenhuismanagement. Er zijn inderdaad vele capabele en coöperatieve ziekenhuismanagers, maar er is geen substituut voor de autoriteit van artsen over het proces van de operaties van een ziekenhuis. Artsen moeten bereid zijn bestuurlijke verantwoordeiijkheid te accepteren in hun instituten. Onze voor- 
keur gaat uit naar de operatiekamer en we vinden het verrichten van operaties het meest interessant; maar terwijl we ons verder ontplooien en operatietechnieken vervolmaken, moeten we toch een deel van onze tijd steken in bestuurlijke taken en enkelen van ons moeten al hun tijd erin steken. We kunnen simpelweg geen afstand doen over de controle van onze werkomgeving. De gerenommeerde chirurg Loop deed in 1998 tijdens zijn presidentiële toespraak van de American Association for Thoracic Surgery het volgende statement "De eerste belangrijke les die ik geleerd heb in het management is dat medische centra geleid zouden moeten worden door artsen/specialisten. Het is gemakkelijker voor een arts om zakelijk management te leren dan voor een zakenman/manager om medicijnen te leren". De uitspraken van deze twee beroemde academische Cardiothoracaal Chirurgen illustreren duidelijk de noodzaak voor academische chirurgen om managementvaardigheden aan te leren. De academisch chirurg moet in de eerste plaats wel klinisch werkzaam zijn en in de tweede plaats onderzoeker, maar betrokkenheid in bestuurlijke taken is essentieel. De meeste jonge academische chirurgen, die met goed gevolg hun moeilijke chirurgische opleiding hebben voltooid zijn het meest geinteresseerd om zichzelf te bewijzen dat ze zelfstandig operaties met goed resultaat kunnen verrichten. De tweede prioriteit voor de meeste chirurgen is het ontwikkelen van een onderzoekslijn of researchplan. Dit gebeurt in samenhang met de verwachting dat het hoofd van de afdeling zorgdraagt voor de noodzakelijke logistieke ondersteuning, zoals adequate operatiekamerfaciliteiten en voldoende ruimte voor research om het mogelijk te maken deze doelen te bereiken. De meeste jonge academische chirurgen vertonen weinig interesse in de organisatorische, administratieve kanten om deze plannen tot een succes te laten 
worden. In feite is het mogelijk om een redelijk succesvolle academische carrière te doorlopen, in het bijzonder op een klinisch onderwerp, zonder de daarbij behorende vele administratieve vaardigheden aan te leren of geen betrokkenheid ten toon te spreiden voor bestuurlijke taken. Maar indien u meer wil zijn dan een solist of een éendimensionaal staflid van een vakgroep en u meer aspiraties heeft zoals hoofd van een afdeling of voorzitter van een vakgroep of van een super- of subspecialisme en op nationaal niveau een rol als leider ambieert, dan zijn betrokkenheid met administratieve taken en de ontwikkeling van organisatorische talenten, belangrijke instrumenten om het $u$ mogelijk te maken deze doelen te bereiken en wat belangrijker is dat het een voorwaarde is, indien $u$ deze positie zou bereiken. Zelfs indien uw aspiraties niet zo hoog liggen, dan maken administratieve vaardigheden het $u$ mogelijk een zodanige invloed uit te oefenen op de dagelijkse gang van zaken in uw ziekenhuis, dan eenvoudigweg te klagen en nogmaals te klagen hoe slecht anderen het doen. In uw carrière zult $u$ altijd individuen tegenkomen die op een hoog academisch niveau werkzaam zijn, maar helaas hopeloos ongeschikt zijn als bestuurder of manager.

Een andere voorwaarde voor verandering of vernieuwing is creativiteit. Creativiteit in de chirurgie is niet verschillend van elk ander gebied in onze cultuur. Creatieve chirurgen zijn chirurgen die met nieuwe operaties, nieuwe ideeën of nieuwe materialen te voorschijn komen. Zij hebben een aangeboren nieuwsgierigheid en drang om zaken te zien waar an. deren geen oog voor hebben. Veel chirurgen zịn creatief, maar alleen op het persoonlijke vlak. Zij kunnen hun collegae dan niet overtuigen dat ze creatief bezig zijn. Hun collegae zijn de bewakers van het chirurgisch specialisme en dicteren hoe het uitgevoerd moet worden. Zij zijn de rech- 
ters van de chirurgische creativiteit. Alhoewel we het met de rechters niet eens zijn, zijn ze noodzakelijk, want zonder hun beoordeling is er geen betrouwbare manier om te bepalen of de claims van een creatieve chirurg valide zijn. Wie heeft het bij het juiste eind? De chirurg die in zijn eigen creativiteit gelooft of alle chirurgen die het ontkennen? Het is in de huidige tijd ook moeilijk om in meer dan een domein van uw vakgebied te excelleren. Dat is de reden waarom meer en meer chirurgen zich steeds meer als superspecialist opstellen. Om creatief te zijn moet men diepte-inzicht hebben in het domein van het vakgebied. Net zoals een musicus kennis van zaken heeft over muziek om nieuwe liedjes te schrijven, moet een chirurg zijn specialisme goed overzien om een nieuwe operatie of een nieuw apparaat te ontwikkelen. Thomas Edison heeft gezegd: creativiteit is $1 \%$ inspiratie en $99 \%$ perspiratie. Een echt innovatieve operatie is zelden het resultaat van een plotselinge toeval, maar vaker is dit het resultaat van jaren hard werken. Concentratie en aandacht zijn absoluut noodzakelijk om nieuwe kennis op te doen. Immers een groot deel van onze aandacht wordt opgeslokt door de dagelijkse taak van patiëntenzorg en de organisatie eromheen. Het vraagt veel van ons als chirurgen om de taak als chirurg naar behoren te verrichten en tegelijkertijd nieuwe, essentiële informatie op te nemen tijdens een operatie. Het vereist een ongelooflijke vorm van zelfdiscipline om ons aandachtsgebied uit te breiden om nieuwe ideeën te ontwikkelen en zaken vanuit een andere gezichtshoek te bekijken. Het moment waarop ons dit lukt is het begin van een aanzet tot creativiteit. Naast bovengenoemde voorwaarden hoort ook een dosis geluk. Creatieve individuen zien zichzelf vaak als gelukkige mensen. Voor creatieve individuen is het belangrijk dat ze op de juiste plaats zitten op het juiste tijdstip. Degene die dan de kans aangrijpt om creatief te zijn. 
zijn de gelukkigen. Creativiteit is een kwaliteit van degene die zichzelf kent, met name zijn sterke en zwakke kanten en eigen kwaliteiten en weet hoe ze het best presteren. De sleutel tot creativiteit is om het juiste uitdagende domein te vinden. Men moet dan wel de kennis over het hele domein beheersen en in staat zijn het te veranderen. Intellectuele arrogantie is verwoestend voor creativiteit. Een domein waar de capaciteitsgroep CTC in tracht te excelleren en creativiteit ten toon stelt, is de chirurgie voor het atriumfibrilleren. Toen ik mijn opleiding in de Cardiothoracale Chirurgie volbracht had en zelfs vele jaren daarna, attendeerde mijn opleider mij erop dat ik niet moest geloven dat mijn opleiding compleet was en dat ik niet moest denken dat ik alles van het vak wist en beheerste.

\section{De vorming tot leiderschap in academische Cardiothoracale Chirurgie}

De essentiële kenmerken van leiderschap zijn in vele managementboeken beschreven. De principes van leiderschap zijn belangrijk in alle chirurgische organisaties of het nu een divisie of een nationale organisatie betreft. Bepaalde belangrijke kwaliteiten die toegespitst kunnen worden op ons specialisme zijn charisma, eerlijkheid, integriteit en een voorbeeldfunctie voor anderen om ons heen. Om een goede chirurgische leider te worden is een vereiste dat men goed communiceert en dat men probeert de beste chirurg uit zichzelf te halen, want chirurgen onderling hebben een

- zeer hoog respect voor chirurgen die goede chirurgie bedrijven. Met leiderschap neemt men verantwoordelijkheid om richting te geven aan de handelwijze van anderen om de doelen of beleidslijnen van de capaciteitsgroep of divisie uit te dragen, waarbij men verantwoordelijk is voor zowel suc- 
ces als falen. Tevens heeft men de capaciteit om de juiste beslissingen te nemen en zorgt men voor degenen die voor $u$ en met $u$ werken. Er zijn vier redenen waarom leiderschap van belang is voor de hedendaagse geneeskunde: artsen nemen een belangrijkere rol in de politiek en het beleid van de gezondheidszorg. Kwaliteitscontrole en beleid vragen leidinggevende activiteiten van artsen. Leiderschap is belangrijk om er zeker van te zijn dat de chirurgie niet devalueert tot een bezigheid die innovatie in de weg staat. Uiteindelijk is leiderschap van cruciaal belang in de chirurgie voor innovatie en de vertaling van kennis in een klinische toepassing. Leiderschap kan niet onderwezen worden; het is net als ervaring, maar leiderschap vindt zijn inspiratie door gezond verstand en door voorbeelden. Een ander aspect van leiderschap is de functie van een wijs en betrouwbaar adviseur of gids. Ons professionele leven kan in zijn algemeenheid verdeeld worden in drie fasen: educatie, hard werken om een bepaalde plaats te verwerven en het resultaat een leidinggevende positie. De laatste fase die we typisch als het mentorschap kunnen omschrijven. In het algemeen vereist het mentorschap een maturiteit, zelfvertrouwen en de bereidheid om tijd en energie te steken in meer dan alleen onderwijs. De mentor is meestal ouder dan de protégé en is iemand die veel ervaring verkregen heeft en een seniorpositie verworven heeft. Het mentorschap is cruciaal voor een academische setting; $u$ kunt jongere chirurgen positief beïnvioeden waar u ook bent. De rol van de mentor dient om u inzicht te geven om beter te presteren, maar ook beter te dienen, om te overleven en op te bloeien tot een succesvolle levensloop en in ons geval voor een lange carrière in een mooi beroep. Het proces van mentorschap gebeurt vaak informeel. Het is van cruciaal belang voor de ontwikkeling van de hoogste persoonlijke standaarden, waarvan de meest 
fundamentele standaard kennis is. Het begint in feite bij de universiteit dat het nastreven van kennis gedurende het hele leven moet plaatsvinden. In de Cardiothoracale Chirurgie worden we overweldigd door moderne technologie en de exponentiële groei van informatie. De huidige halfwaarde tijd voor het opslaan van kennis is ongeveer drie tot vijf jaar en het wordt alleen maar korter. Het probleem is niet dat we vergeten wat we hebben geleerd, maar de strijd om nieuwe kennis te vergaren. Nieuwe kennis is de ware rijkdom en is belangrijker dan materiële zaken. Het wil niet zeggen dat u aspiraties moet hebben in eenvoud te leven, maar uw prioriteiten in juist perspectief moet zien. Artsen, in het bijzonder chirurgen, hebben een immature, ongebreidelde wens naar een zekere vrijheid, die niet gecontroleerd wordt door het management of bestuur. Dat is een goede eigenschap. maar we hebben een lange en duurzame carrière te gaan, waarbij we onze concentratie of aandacht op een hoog niveau dienen te houden, hetgeen weer disciplinair handelen vereist. Afgezaagdheid, zo niet verveling is vaak te wijten aan een verlies aan initiatief voor nascholing of bijscholing en zich alleen te bekommeren om materiële zaken. De mentor die de geneeskunde i.c. Cardiothoracale Chirurgie uitdraagt kan de jongere collegae laten zien dat het mogelijk is om de intellectuele drijfveer of ambitie vast te houden. Ongeinspireerde chirurgen komen vaak met het excuus dat ze geen goede opleiders zijn en daardoor niet aan continue nascholing doen en de eigen verantwoordelijkheid voor de nascholing voor henzelf verliezen. Deze statement heeft de gerenommeerde chirurg Floyd Loop in 1998 gedaan in zijn rede voor de American Association for Thoracic Surgery met als titel: "The first living and the last dying". Heden ten dage is de Cardiothoracale Chirurgie veiliger dan toen onze voorgangers(pioniers) het vakgebied ontwikkelden. Maar 
het leven van een chirurg is complexer. ledere chirurg is nu verantwoordelijk voor kosten en kwaliteit en een levenslang leerproces. In de harde wereld van de algemene gezondheidszorg, bestaat er een algeheel pessimisme over de toekomst van de geneeskunde. De vooruitzichten voor honoreringen zien er somber uit en dientengevolge een tekort aan medisch personeel, artsen en de verdere toekomst van uitgebreide regelgeving, competitie en claims, die men elkaar oplegt. Maar desondanks zal de leider of mentor de toekomstige generatie de weg wijzen, dat er voor elk probleem een oplossing is. Elke jonge chirurg heeft een mogelijkheid, en wel de mogelijkheid om het beter te doen of slechter. $U$ moet hem aan kunnen tonen dat het leven vol keuzes is. $U$ moet de assistenten in opleiding eraan blijven herinneren dat de beste chirurgen nooit hun fouten vergeten en men moet ieder jaar proberen beter te worden ondanks het politieke moeras en veranderingen in de politiek van de gezondheidszorg. En vergeet $u$ nooit, dat kritische zelfbeschouwing belangrijker is dan competitie. De beste soort competitie is competitie met $u$ zelf, competitie om elk jaar beter te worden. Patiënten komen nog steeds bij ons, één voor één, en niet als een set gegevens uit een databank. Chirurgie is niet alleen een belangrijke uitdaging, maar is ook een continue uitdaging. Cardiothoracale Chirurgie is een groot privilege, en het echte privilege is de zorg voor de patiënt. Alhoewel we ervaring niet kunnen aanleren, kunnen we wel volharding aanleren en het belang van bijscholing, ingenuiteit, en ondernemingszin. $U$ weet wat volharding is; volharding is het harde werken dat $u$ doet nadat $u$ moe bent geworden van het harde werken dat $u$ reeds verricht hebt. Dat is wat $u$ kan overbrengen. Maar al te vaak is het individu die de opleiding met succes volbracht heeft alleen geïnteresseerd in inkomen, wat op de korte termijn van minder belang is. Voor uitdagingen 
op lange termijn zal de jonge chirurg aan de frontlijn van de Cardiothoracale Chirurgie moeten staan, waarbij de versnelde ontdekkingsreis op het gebied van wetenschap, technologie en klinische praktijk, deze grote chirurgische onderneming intellectueel stimulerend werkt en genoegdoening geeft. Anders is het chirurgenleven saai en droog.

Dit continuum van blijven leren, meegaan met veranderingen en het initiëren hiervan, zal ik, samen met de staf Cardiothoracale Chirurgie, de komende jaren aan de afdeling vorm en inhoud geven, waarbij u een leidende rol van ons mag verwachten.

\section{Dankwoord}

Mijnheer de rector Magnificus, dames en heren, Ik heb een bijzondere taak aanvaard, een boeiende taak en ook een uitdagende. Maar het is alleszins de moeite waard. Het creatief bezig zijn in een academische setting, waarin ik de ruimte krijg om vraagstukken betreffende gezondheidszorg, onderwijs en onderzoek te regelen, geeft veel voldoening. Het gezamenlijk enthousiasme dat ik steeds proef binnen het samenwerkingsverband met de collegae hoogleraren $M$. Jacobs, H. Crijns, M. Durieux en M. Wouters werkt erg stimulerend. I heb goede herinneringen aan mijn lange Rotterdamse periode in het Thoraxcentrum van het Academisch Ziekenhuis Rotterdam en het Zuiderziekenhuis.Tijdens mijn korte periode van twee en een half jaar in het Onze Lieve Vrouwe Gasthuis te Amsterdam kon ik de academische uitdaging, aanbod vanuit Maastricht niet weerstaan. Ik ben de Raad van Bestuur van het Academisch Ziekenhuis Maastricht, het College van Bestuur van de Universiteit en het Faculteitsbestuur Geneeskunde zeer erkentelijk 
voor het vertrouwen dat in mij gesteld is om deze taak uit te voeren. Veel mensen hebben hun bijdrage geleverd aan mijn vorming, ieder op hun eigen manier. Het is onmogelijk allen die een bijdrage aan mijn professionele vorming hebben geleverd nu iets te zeggen, maar enkelen wil ik hierbij noemen en bedanken.

Hooggeleerde Nauta, beste Jan het was een bijzonder groot voorrecht om in 1977 het team in het Thoraxcentrum te mogen versterken. Ik heb deze kans met beide handen aangegrepen. Het was bij tijd en wijle een harde leerschool, maar noodzakelijk voor mijn vorming tot hartchirurg. Ik was in 1981 de jongste cardiopulmonaal chirurg in Nederland en mocht tot jouw staf behoren. Dankbaar en met veel respect denk ik terug aan Andre Fredriksz, zaliger, een van mijn leermeesters. Hij heeft mij gewezen hoe centraal de zorg voor de patiënt staat.

Hooggeleerde Bos, beste Egbert onder jouw leiding heb ik me ontplooid en heb ik veranderingen ondergaan, maar ben ik hopelijk toch mezelf gebleven. De ruimte die je me met het harttransplantatieprogramma hebt gegeven, zijn in mijn vorming van onschatbare waarde gebleken. Inzet, commitment en loyaliteit zijn begrippen, die ik ook probeer over te dragen op de volgende generatie. Ik zal de fakkel van je overnemen.

Hooggeleerde Weimar, beste Willem als een van je eerste promovendi ben ik nu ook de eerste hoogleraar, die een groot deel van zijn wetenschappelijke vorming aan jou te danken heeft. In Maastricht heb ik vele plannen, waarbij ik jouw werkwijze als voorbeeld zal nemen. 
Weledelzeergeleerde Vrouwe Balk, beste Aggie onze professionele relatie waarbij de harttransplantatie-patiënt centraal stond, is een samenwerking waar vele van onze collegae een voorbeeld aan kunnen nemen.

Mijn ouders, pa en ma, de enorme opoffering noch moeite die jullie getroost hebben om mij te laten leren, studeren en mijn specialisatie te volbrengen, zijn uiteindelijk beloond. Jullie missie is volbracht. Wanda, al 20 jaar sta je achter mijn loopbaan. Ik dank je voor je aandacht, geduld en aanpassingsvermogen, altijd. Fendi, Yoeri en Kenneth, ik hoop dat ik een goed voorbeeld voor jullie ben.

Ik heb gezegd. 


\section{Literatuur}

1. Hatcher CR. There is life outside the operating room. Ann Thorac Surg 1988:45:117-21

2. Helmreich RI, Schaefer HG. Team performance in the operating room. In: Bogner MS, editor. Human error in medicine. Hillside (NJ): Lawrence Erlbaum; 1994.

3. Loop FD. The first living and the last dying. J Thorac Cardiovasc Surg 1998;116:683-8

4. Baumgartner AW, Greene PS. Developing the academic thoracic surgeon: teaching surgery. J Thorac Cardiovasc Surg 2000:119:4:S22-S25. 